\title{
Zbigniew Jurczyk
}

Wyższa Szkoła Bankowa we Wrocławiu

e-mail: zbjur@op.pl

ORCID: 0000-0002-4089-354X

\section{ZASADA SPRAWIEDLIWEJ WYMIANY A MARKETING}

\section{PRINCIPLE OF FAIR \\ EXCHANGE VS. MARKETING}

DOI: 10.15611/pn.2018.530.14

JEL Classification: D180, M390

Streszczenie: Współczesne koncepcje marketingu wskazują, że skuteczny marketing powinien być obecnie zorientowany przede wszystkim na potrzeby klienta. Przyjmowanie perspektywy klienta to jednak również akceptowanie zasad i wartości, których przestrzegania w marketingu oczekują klienci. Taką najważniejszą zasadą w relacjach typu B2C jest zasada sprawiedliwej i uczciwej wymiany. Wynika ona z podstawowych praw konsumenta. Zasada ta jednak jest najczęściej naruszana wskutek świadomych i celowych działań marketingowych, które wprowadzają konsumentów w błąd, wskutek czego podejmują oni decyzje o zakupie towarów lub usług, których w innych okolicznościach by nie podjęli. Tak więc mimo że kolejne modele marketingu mówią coraz więcej o jego społecznych funkcjach i o marketingu opartym na wartościach, to kluczowa wartość dla konsumentów, którą stanowi zasada sprawiedliwej i uczciwej wymiany, jest wciąż w nim pomijana. Celem niniejszego opracowania było wskazanie potrzeby włączenia do teorii marketingu wartości należącej do zbioru praw konsumenta, którą jest przestrzeganie przez przedsiębiorców w relacjach z konsumentami zasady sprawiedliwej i uczciwej wymiany.

Słowa kluczowe: sprawiedliwa wymiana, prawa konsumenta, satysfakcja konsumenta, marketing.

Summary: Contemporary marketing concepts teach us that current marketing should be first and foremost oriented towards consumers' needs. But adopting the client's perspective means also accepting the principles and values which clients expect to be respected in marketing. The most important principle in $\mathrm{B} 2 \mathrm{C}$ relationships is the principle of fair and honest exchange. This principle arises from the fundamental rights of consumers. It is, however, violated most frequently by informed and targeted marketing activities which mislead consumers with the result that they make decisions to purchase goods or services, which under different circumstances they would not make. Despite the fact that subsequent marketing models speak increasingly more often about social functions of marketing and about a marketing that is based on values, the key value, which for consumers is the principle of fair and honest exchange, continues to be disregarded. The aim of this paper is to show the need for including in the marketing theory the value, it being part of the set of consumer rights, which is respecting the principle of fair and honest exchange in the relationships with consumers

Keywords: fair exchange, consumer rights, consumer satisfaction, marketing. 


\section{Wstęp}

Problem sprawiedliwej wymiany w marketingu w niniejszym opracowaniu dotyczy relacji budowanych instrumentami marketingowymi przez przedsiębiorcę z konsumentem. Jest on ważnym zagadnieniem wchodzącym w zakres ochrony interesów konsumenta oraz budowania jego relacji z przedsiębiorcami. Ujęcie problemu sprawiedliwej wymiany w kontekście marketingu nie będzie w związku z tym omawiane od strony etyki. W prezentowanych rozważaniach stanowi ona kryterium prawne i psychologiczne stosowane przez konsumentów do oceny i wartościowania skierowanych wobec nich przedsięwzięć marketingowych. Inaczej mówiąc, będzie to spojrzenie na marketing oczami konsumenta przez pryzmat respektowania $\mathrm{w}$ nim zasady sprawiedliwej i uczciwej wymiany.

Konsument w obrocie gospodarczym jest podmiotem definiowanym zarówno przez teorię ekonomii, jak i przez prawo. Konsument w teorii ekonomii jest podmiotem stosunków rynkowych nabywającym dobra i usługi finalne od przedsiębiorcy detalicznego w celu zaspokojenia swoich potrzeb. W teorii ekonomii najważniejszą sprawą z punktu widzenia konsumenta jest tworzenie warunków funkcjonowania rynku w celu zachowania jego suwerenności [Jurczyk 2016, s. 72]. Konsument w gospodarce rynkowej został także zdefiniowany w prawie cywilnym, którego ważną częścią obecnie stało się prawo ochrony konsumentów. Za konsumenta uważa się osobę fizyczną dokonującą z przedsiębiorcą czynności prawnej niezwiązanej bezpośrednio z jej działalnością gospodarczą lub zawodową ${ }^{1}$. Konsumenta uważa się za najsłabszą jednostkę rynku, a jednocześnie za najważniejszą jako nabywcę, a zatem również decydującego o sukcesach lub porażkach przedsiębiorcy. Celem prawa konsumentów jest zatem wzmocnienie prawnej i ekonomicznej pozycji konsumenta na rynku poprzez ochronę jego istotnych interesów ekonomicznych, naruszanych przez przedsiębiorców w wyniku stosowania nieuczciwych i agresywnych praktyk rynkowych, w tym głównie o charakterze marketingowym. Działania marketingowe tego rodzaju obejmują wszystkie czynności, o których mówią modele marketingu 4P i 7P. Konsument w tych modelach marketingu nie jest jednak główną postacią, taką postacią bowiem jest klient. Patrzenie na funkcję marketingu przez pryzmat klienta, a nie konsumenta sprawia, że wartości, jakie identyfikuje i zaspokaja marketing dotyczą wartości materialnych i niematerialnych, które dostarczane są konsumentom dzięki zastosowaniu jednej z trzech strategii: najniższa cena, najlepszy produkt, najlepsza obsługa [Przybyłowski i in. 1998, s. 16]. Wśród nich nie ma jednak wartości, które definiuje polityka konsumentów i określa prawo ochrony konsumentów. Jedną z tych wartości jest oparcie relacji pomiędzy konsumentami a przedsiębiorcami $\mathrm{w}$ fazie przedtransakcyjnej, $\mathrm{w}$ fazie transakcji i w fazie posttransakcyjnej na zasadzie sprawiedliwej i uczciwej wymiany. I chociaż, jak wynika to z dalszych rozważań, wiele aspektów społecznych działalności gospodarczej zostało włączanych do teorii

\footnotetext{
${ }^{1}$ Artykuł $22^{1}$ Kodeksu cywilnego.
} 
marketingu w ostatnich kilkunastu latach, szczególnie poprzez stworzenie koncepcji marketingu 3.0 oraz marketingu 4.0, to aspekty zasady sprawiedliwej i uczciwej wymiany są wciąż pomijane, zarówno w teorii marketingu, jak i w marketing stosowanym. Era marketingu opartego na wartościach, aczkolwiek zakłada skorelowanie misji, wizji i wartości firmy z oczekiwanymi wartościami klientów, nie dostrzega wartości zawartych w podstawowych prawach konsumenta. Na taką właśnie negatywną stronę marketingu wskazują liczne sprawy prowadzone przez instytucje ochrony konsumentów o naruszenie tzw. zbiorowych interesów konsumentów. Z praktyki tych organów, a szczególnie Urzędu Ochrony Konkurencji i Konsumentów, wynika że najczęściej są to nieuczciwe praktyki rynkowe o charakterze marketingowym² ${ }^{2}$. Ze skarg konsumentów, jakie napływają do UOKiK, wynika, że działania marketingowe ze strony przedsiębiorców były celowe i świadome, a w przypadku marketingu bezpośredniego transakcje zawierane były często pod wpływem presji i nacisku w postaci silnej i kłamliwej perswazji ${ }^{3}$.

Nieuczciwość marketingowych praktyk rynkowych ma dwa wymiary: wymiar prawny, którego kryteria sformułowane są przez prawo konsumenckie [Ustawa z dnia 23 sierpnia 2007 r.], oraz wymiar psychologiczny, który opisuje stany emocjonalne, kategorie ocenne konsumenta powstałe w związku z jego subiektywnym odczuciem jako ofiary niesprawiedliwej wymiany. Zasadę sprawiedliwej wymiany $\mathrm{w}$ jednym i drugim wymiarze narusza marketing stosowany, gdy komunikaty i działania marketingowe o produkcie i usłudze są nieuczciwe, informacje przekazywane są kłamliwe, zafałszowane, ukrywane, niepełne. Są one podejmowane przez przedsiębiorcę w sposób celowy i świadomy z zamiarem wprowadzenia konsumenta w błąd, wywołania u niego konfuzji co do podjęcia decyzji, których nie podjąłby, gdyby działania marketingowe przedsiębiorców nie nosiły znamion nieuczciwych praktyk rynkowych.

Celem niniejszego opracowania jest wskazanie potrzeby włączenia do teorii marketingu wartości należącej do zbioru praw konsumenta, którą jest przestrzeganie przez przedsiębiorców $w$ relacjach $z$ konsumentami zasady sprawiedliwej i uczciwej wymiany. Nieprzestrzeganie tej zasady prowadzi do naruszenia istotnych interesów ekonomicznych, konsumentów, a w warstwie psychologicznej - do braku satysfakcji i subiektywnej niesprawiedliwości. Dalsze rozważania poświęcone zostaną właśnie tym ważnym zagadnieniom.

\section{Przykłady praktyk marketingowych naruszających zasadę sprawiedliwej i uczciwej wymiany}

Praktyki marketingowe zakłócające zasadę sprawiedliwej i uczciwej wymiany są częścią nieuczciwych praktyk rynkowych godzących w ekonomiczne interesy kon-

\footnotetext{
${ }^{2}$ Informacje o tego typu praktykach zawierają coroczne Sprawozdania z działalności UOKiK.

${ }^{3}$ Taki marketing jest stosowany szczególnie w stosunku do osób starszych podczas sprzedaży produktów leczniczych, suplementów diety, zmiany dostawcy energii czy operatora telefonicznego.
} 
sumenta. Prawo konsumenckie przez praktykę rynkową rozumie działanie lub zaniechanie przedsiębiorcy, sposób postępowania, oświadczenie lub informację handlową, w szczególności reklamę i marketing, bezpośrednio związane z promocją lub nabyciem produktu przez konsumenta ${ }^{4}$. Ten przepis prawny wprost wskazuje nie tylko reklamę, ale i pozostałe działania i przekazy marketingowe, które powodują lub mogą powodować podjęcie przez przeciętnego konsumenta decyzji dotyczącej zawarcia umowy, zakupu różnego rodzaju produktów lub usług, której by nie podjął, gdyby nie został celowo zmanipulowany i wprowadzony w błąd. Skoro takiej decyzji konsument by nie podjął, to znaczy, że w percepcji konsumenta transakcja okazała się z jego punktu widzenia niesprawiedliwa, ponieważ albo była ona nieekwiwalentna pod względem ekonomicznym, czyli konsument otrzymał mniej wartościowy produkt, niż za niego zapłacił, albo w ogóle by nie podjął decyzji o zawarciu umowy, gdyby nie został wprowadzony w błąd co do wartości posiadanych przez oferowany produkt lub usługę. Niesprawiedliwość ta oceniana jest także przez konsumenta w kategoriach psychologicznych, czego odbiciem jest jego stan niezadowolenia lub rozczarowania, gdy reklamowane parametry użytkowe (wartości) produktu okazały się gorsze albo inne niż zachwalane w przekazie marketingowym. Nieuczciwe praktyki marketingowe, wywołując u konsumenta konfuzję co do oceny realnej sytuacji zakupowej, mają faktyczny wpływ na decyzje rynkowe konsumenta dotyczące promowanego produktu lub usługi.

Szczególne konfuzje i zaburzenia wywołuje reklama wprowadzająca konsumenta w błąd ze względu na zawarte w niej intencje. Jak stwierdził SN, wyznacznikiem przekazu reklamowego jest nie tylko mniej lub bardziej wyraźna zachęta do kupna towaru, ale również faktyczne (rzeczywiste) intencje podmiotu dokonującego przekazu oraz odbiór przekazu przez podmioty, do których jest kierowany ${ }^{5}$. Reklamą zaś może być każda wypowiedź, gdy w przekazie informacyjnym przeważa zachęta, bodziec natury ekonomicznej lub emocjonalnej do nabycia towaru lub usługi i taki jest cel nadawcy wypowiedzi, tak też odczytuje ją przeciętny odbiorca, do którego została skierowana ${ }^{6}$. Reklamę w świetle sądów kwalifikuje się jako wszelkie formy przekazu, bez względu na sposób i rodzaj użytego środka, których celem jest wywieranie wpływu na decyzje ekonomiczne jej odbiorców w zakresie skorzystania z oferty reklamowej, jak i formy przekazu pozbawione elementów zachęcających do nabycia produktu, lecz z punktu widzenia nadawcy i odbiorcy kwalifikowane jako zachęta do kupna ${ }^{7}$. Skutkiem wprowadzenia w błąd przez reklamę jest naruszenie prawa konsumenta do podjęcia suwerennej (swobodnej) decyzji rynkowej. Cechuje ją bowiem zwodnicza natura, gdy poprzez wytworzenie nieprawdziwego, niezgodnego z rzeczywistością obrazu towaru lub usługi zmierza do zniekształcenia zachowania

\footnotetext{
${ }^{4}$ Zob. [Ustawa z dnia 23 sierpnia 2007 r., art. 2, pkt 4].

${ }^{5}$ Wyrok SN z dnia 2 października 2007 r., II CSK 289/2007, OSN 2008, nr 12, poz. 140.

${ }^{6}$ Tamże.

${ }^{7}$ Zob. [Ustawa o zwalczaniu nieuczciwej konkurencji 2016, s. 789].
} 
rynkowego odbiorcy reklamy ${ }^{8}$. Reklamę wprowadzająca w błąd w świetle prawa traktuje się także jako reklamę oszukańczą. Istotność oszukańczej reklamy ma wprawdzie wpływ na szkodę majątkową konsumenta, w związku z podjęciem błędnej decyzji, ale nie jest to konieczna przesłanka prawna takiej kwalifikacji甲. Reklama wprowadzająca w błąd występuje najczęściej wówczas, gdy komunikat reklamowy zawiera fałszywe, nieprawdziwe lub niepełne informacje. W praktyce zdarza się jednak, że reklamy zawierające obiektywnie prawdziwe informacje mogą również wprowadzać w błąd ze względu na sposób ich przekazania, gdy są to informacje niepełne, dwuznaczne, trudno sprawdzalne lub podano je w mało zrozumiany i dostępny sposób ${ }^{10}$.

Oto kilka przykładów praktyk marketingowych przedsiębiorców, przeciwko którym UOKiK prowadził postępowanie o naruszenie zbiorowych interesów konsumentów.

Przykład I. Praktyka Aflofarm Farmacja Polska Sp. z o.o. Praktyka tej firmy dotyczyła reklamy suplementu RenoPuren Zatoki Hot i RenoPuren Zatoki Junior w telewizji i w Internecie w latach 2015-2016. Suplementy diety (które są środkami spożywczymi) były reklamowane tak, aby przekonać konsumentów, iż mają właściwości lecznicze. Była to scenka, w której autorka grająca postać lekarki sugerowała, że po zażyciu suplementu dolegliwości z zatokami ustąpiły. Wzmacniały ją napisy „oczyszcza zatoki, podnosi odporność, zdrowe zatoki na długo”. Na zlecenie UOKiK TNS przeprowadził ankietę, jak widzowie odbierali kwestionowane reklamy. Badanie wykazało, że większość konsumentów, kupując suplementy, było przekonanych, iż mają one właściwości lecznicze. Konsumenci nie tylko zostali wprowadzeni w błąd, ale podczas zakupu tego produktu doszło do niesprawiedliwej wymiany. Firma została ukarana grzywną w kwocie $26 \mathrm{mln}$ i zobowiązana do publikacji na własny koszt w TVP 1 i Polsat, YouTube informacji o tym, że wprowadzała konsumentów w błąd ${ }^{11}$.

Przykład II. Praktyka Spółki Multi-Import S.C. Spółka sprzedawała na platformie allegro.pl podgrzewacze do butelek Snow Bear. W opisie części modeli Snow Bear zapewniała, że czasopismo „Baby” uznało je za najlepsze i najmniej awaryjne na rynku. Po tym, jak wyszło na jaw, że taki magazyn nie istnieje, spółka zamieściła na Allegro informację o sklasyfikowaniu oferowanych podgrzewaczy jako najlepszych i najmniej awaryjnych na rynku, bez wskazania autorstwa i metody rzekomo dokonanej klasyfikacji. Zapewniała też, że podgrzewacze i pojemniczki do pokarmu zbadał Sanepid, co okazało się również nieprawdą. UOKiK uznał, że zamieszczane w opisie nieprawdziwe i nierzetelne informacje stanowią nieuczciwą praktykę rynkową, ponieważ wprowadzały one kupujących w błąd. Mogły zatem skłonić konsu-

\footnotetext{
${ }^{8}$ Wyrok SA w Poznaniu z dnia 14 września 2005 r., I ACa 149/05, OSA 2006, z. 1, poz. 34.

${ }^{9}$ Tamże, s. 831.

${ }^{10}$ Mogą to być np. informacje podane małą czcionką, bladym drukiem lub trudno zauważalne.

${ }^{11}$ Decyzja Prezesa UOKiK z dnia12.10.2017, Nr DOIK 5/2017.
} 
mentów do zakupu podgrzewaczy, na co w innych okolicznościach by się nie zdecydowali. Prezes UOKiK nałożył na troje wspólników spółki cywilnej kary finansowe za każdą z nieprawdziwych informacji - w sumie ponad 15 tys. zł. Dodatkową sankcją był nakaz zamieszczenia komunikatu o decyzji UOKiK na portalu allegro.pl ${ }^{12}$.

Przykład III. Praktyka Polskiej Telefonii Stacjonarnej SA. W trakcie marketingu bezpośredniego przedstawiciele PTS, proponując obniżkę abonamentu, dawali do zrozumienia, że reprezentują dotychczasowego operatora. Umowa zawierana była za pośrednictwem kurierów dostarczających konsumentom do mieszkań odpowiednie dokumenty, jak umowa, regulamin, cennik, wzór odstąpienia od umowy, regulamin promocji. Po podpisaniu umowy przez konsumentów kurierzy zabierali całość bądź część dokumentów do PTS. Kopie umów były odsyłane konsumentom dopiero po upływie 14 dni, a więc po terminie, w którym mogli oni odstąpić od umowy zawieranej poza siedzibą przedsiębiorstwa. Ponadto regulamin, który stanowił załącznik do umowy, napisany został zbyt małą czcionką, a układ dokumentów utrudniał zapoznanie się z jego treścią. Na działania spółki do UOKiK wpłynęło ponad 700 skarg od konsumentów. UOKiK uznał, że PTS swoimi działaniami naruszyła prawa konsumentów, wprowadzając ich w błąd, wskutek czego podjęli decyzje, których $\mathrm{w}$ innych warunkach by nie podjęli, oraz pozbawiła ich prawa do odstąpienia umowy po zorientowaniu się, iż zawarli umowę z nowym operatorem. UOKiK nakazał zaniechania stosowania zakwestionowanych praktyk oraz nałożył na PTS karę w wysokości 353679 zł $^{13}$.

\section{Ekonomiczne, psychologiczne i prawne aspekty zasady sprawiedliwej i uczciwej wymiany}

Idea sprawiedliwej i uczciwej wymiany powinna się stać umiejętnie wkomponowaną zasadą w zarządzaniu biznesem. Transakcje typu B2C bowiem dominują w obrocie gospodarczym, a relacje, które z tytułu tych transakcji powstają pomiędzy przedsiębiorcą i konsumentem, stanowią główne środowisko dla marketingu. Struktura tych transakcji nie jest jednak jednowymiarowa. Ich charakterystyką są wymiary ekonomiczny, psychologiczny i prawny. Każda transakcja jest też przez konsumenta oceniana $w$ tych trzech wymiarach. Wspólnym zaś kryterium w tej ocenie i ewaluacji jest kryterium sprawiedliwej i uczciwej wymiany. W związku z tym kluczowe staje się rozpoznanie czynników i uwarunkowań, które składają się na pojęcie i znaczenie tego kryterium.

Poczucie sprawiedliwości jest jednym z najważniejszych kryteriów, które pozwalają jednostkom oceniać, co jest właściwe, a co niegodne lub nieodpowiednie. Jest mechanizmem, który steruje zachowaniem jednostki w życiu prywatnym oraz w roli

\footnotetext{
${ }^{12}$ Decyzja Prezesa UOKiK z dnia 19.09.2017, NR RLU Nr 6/17.

${ }^{13}$ Decyzja Prezesa UOKiK z 31.12.2014, Nr RŁO 39/2015.
} 
pracownika i konsumenta. Podstawą sprawiedliwości są takie atrybuty, jak szczerość, wiarygodność, uczciwość, szacunek, prawość, troska o innych, odpowiedzialność i lojalność. Jest więc oczywiste, że to kryterium nie może być pomijane w biznesie. Dla przedsiębiorców zasada sprawiedliwości jest wprowadzana do praktyki biznesowej najczęściej poprzez kodeksy etyczne i dobrych praktyk. Sprawiedliwość w biznesie jest jednak przede wszystkim wymuszana przez prawo, co, jak wskazano wcześniej, dotyczy także marketingu.

W przypadku konsumenta rola prawa, ze względu na jego słabszą pozycję na rynku, ma szczególne znaczenia dla ochrony jego interesów. $Z$ tego też powodu ochrona ta została również zinstytucjonalizowana poprzez ustanowienie organów stojących na straży przestrzegania praw konsumenta. Zasada sprawiedliwej i uczciwej wymiany w przypadku konsumenta dotyczy nie tylko ceny, czyli nie jest sprowadzona wyłącznie do aspektu ekwiwalentności wymiany, ale także do pokrywania się wartości, których nośnikiem jest zakupiony towar lub usługa, o których sprzedawca przekonywał w swoich działaniach marketingowych. Jest to ocena indywidualna konsumenta oparta na jego własnych kryteriach ewaluacji, którymi są koszty i korzyści. Koszty obejmują zarówno koszty ekonomiczne, jak i psychologiczne. Korzyści to parametry użytkowe, funkcjonalność, ekonomiczność użytkowania, oszczędności czasu, ale także korzyści psychologiczne, jak zadowolenie, przyjemność, radość. Koszty ekonomiczne konsumenta to z kolei wydatek pieniężny, poświęcony czas, wysiłek fizyczny, a psychologiczne to poczucie niesprawiedliwości, oszustwa, zawodu, rozczarowanie.

Problem zagadnienia sprawiedliwej wymiany starał się rozwiązać już św. Tomasz z Akwinu. Skupił się on na rozwiązaniu takiej kwestii w handlu, jaką jest wartość jakiegoś dobra, produktu. Problem ten w historii myśli ekonomicznej jest ujmowany jako zagadnienie ceny słusznej (sprawiedliwej) ulokowane w średniowiecznej teorii sprawiedliwości wymiany opartej na proporcjonalności ceny do pracy i materiałów poświęconych na wykonanie towaru. Św. Tomasz z Akwinu thumaczył, że wymiana sprawiedliwa opiera się na wymianie ekwiwalentów, równości tego, co się daje, z tym, co się otrzymuje, narzucanie na jedną ze stron większych obciążeń byłoby niesprawiedliwością. Ta równość wynika bowiem z procesu produkcji dóbr. W procesie wymiany natomiast zawarte jest pewne ryzyko, ale zgodnie z zasadą ,iustum pretium" w cenie towaru ma zostać zwrócony całkowity koszt produkcji bez szkody dla sprzedającego, ale także bez pokrzywdzenia (nadwyrężenia) nabywcy.

W podejściu tym zasada sprawiedliwej wymiany jest zawężona tylko do ceny i kosztów, pomija się natomiast całą sferę marketingu, która ma istotny wpływ na to, czy cały proces wymiany jest sprawiedliwy i uczciwy. Nieuczciwa sprzedaż (misseling) jest pojęciem opisującym wątpliwy pod względem prawnym i etycznym sposób oferowania i sprzedaży produktów. Na nieuczciwą sprzedaż składać się mogą zarówno zachowania, jak i procedury sprzedaży oraz działania marketingowe, które mają na celu wprowadzenie konsumentów w błąd. Transakcja towarowa typu B2C to bowiem nie tylko w świetle prawa umowa sprzedaży, w ramach której następuje przeniesienie własności na nabywcę. Prawo konsumenckie w ustawie o prawach 
konsumenta nakłada bowiem obowiązki informacyjne na przedsiębiorcę względem konsumenta przed zawarciem umowy, reguluje koszty, którymi może zostać obciążony konsument, prawo do odstąpienia od umowy, odpowiedzialność sprzedawcy za wady rzeczy sprzedanej oraz stanowi o rękojmi i gwarancji konsumenckiej.

Do umowy sprzedaży zawieranej z konsumentem można jednak również podejść jako do pewnego rodzaju sprawiedliwego kontraktu psychologicznego (psychological contract fairness) [Macko 2009, s. 33-58] zawartego między przedsiębiorcą a konsumentem. Na kontrakt ten składa się ogół przekonań i oczekiwań konsumenta na temat transakcji zakupu towaru lub usługi zawartej z przedsiębiorcą. Kontrakt taki jest zrównoważony, sprawiedliwy, gdy obie strony otrzymały to, czego oczekiwały, czyli gdy obie strony kontraktu doznają pełnej satysfakcji. Taki kontrakt będzie zrównoważony, czyli sprawiedliwy, gdy oczekiwania co do poniesionego wkładu i otrzymanych korzyści nie będą rozmijać się z rzeczywistością. Ocena takiego kontraktu psychologicznego przez konsumenta z punktu widzenia sprawiedliwej i uczciwej wymiany ma zawsze charakter subiektywny, indywidualny i jednorazowy. Oznacza to, że każda dana transakcja będzie się różnić od każdej innej transakcji tego rodzaju dokonanej w innym czasie, chociaż w tym samym miejscu i z tym samym przedsiębiorcą. Oczywiście konsumenci mogą mieć również wspólne poczucie sprawiedliwej bądź niesprawiedliwej wymiany dokonywanej z tym samym sprzedawcą, gdy stanowią grupę klientów tego samego przedsiębiorcy (konsument zbiorowy) stosującego względem nich te same techniki promocji i sprzedaży.

Złamanie kontraktu psychologicznego występuje wówczas, gdy konsumenci postrzegają rozbieżność między tym, co obiecywał sprzedawca, a tym, co otrzymali. Z perspektywy konsumenta powstałe rozbieżności odbierane są jako niesprawiedliwe i nieuczciwe ich potraktowanie. Takie zachowania skłaniają konsumentów do podejmowania działań w celu przywrócenia sprawiedliwości na drodze wnoszenie skarg, reklamacji czy występowania z pozwami sądowymi. Złamanie kontraktu prowadzi bowiem do poczucia niezadowolenia, złości, zdrady, irytacji i tym samym do wykorzystania dostępnych środków zaradczych w celu wyrównania poniesionych strat bądź szkód.

W opisanym kontrakcie psychologicznym najważniejszym kryterium (miernikiem) sprawiedliwej wymiany jest satysfakcja konsumenta. Nie ma też w tej koncepcji kolizji między interesem konsumenta i przedsiębiorcy, ponieważ w aktualnym trendzie zarządzania biznesem najważniejszym celem działalności jest sprzedaż wartości, których oczekuje konsument. Jeśli konsument otrzymuje to, czego oczekiwał, i będzie z tego powodu zadowolony i usatysfakcjonowany, to uzna wówczas, że wymiana była uczciwa i sprawiedliwa. Z kolei korzyść przedsiębiorcy z satysfakcji konsumenta jest taka, że będzie osiągał przewagę na rynku nad konkurentami i zyskiwał lojalność konsumentów. Należy jednak pamiętać o pewnych prawidłowościach, jakie pociągają za sobą subiektywne oceny zachowania uczestników wymian społecznych. Pozytywne odstępstwa od kontraktów mają z reguły mniejszą wagę aniżeli negatywne odstępstwa od realizacji zapewnień przedsiębiorcy. Wychodzenie poza oczekiwania konsumentów nie będzie miało tak znaczącej siły jak niedotrzymywanie podjętych obietnic. Dlatego 
też wielu praktyków zarządzania kieruje się zasadą, że lepiej zanadto nie obiecywać, aniżeli ponosić konsekwencje za niedotrzymane obietnice.

\section{Satysfakcja jako kryterium sprawiedliwej i uczciwej wymiany}

Satysfakcja konsumenta stała się obecnie istotnym, często używanym terminem w marketingu. Pozwala ona mierzyć, jak produkty lub usługi dostarczane przez przedsiębiorców konsumentom spełniają lub przekraczają ich oczekiwania. Dla wielu marketingowców i menadżerów stanowi ona ważny barometr, którego używają do zarządzania swoim biznesem i do jego udoskonalania. Pojęciami bliskoznacznymi z pojęciem satysfakcji są zadowolenie, przyjemność, radość, zachwyt, szczęście. $\mathrm{Z}$ kolei brak satysfakcji oznacza niezadowolenie, dyskomfort, frustrację, rozczarowanie. Dbałość o wysoki poziom satysfakcji powinien, jak się uważa w zarządzaniu biznesem, być misją i celem firmy, ponieważ tworzy ona silne relacje z klientem, kreuje jego lojalność oraz buduje pozytywny wizerunek firmy.

Satysfakcja konsumenta jest skutkiem psychologicznego procesu, który przeprowadza we własnym zakresie każda strona kontraktu. W rozważaniach skupiamy się na satysfakcji konsumenta, jaką on odczuwa lub nie w wyniku porównania otrzymanych wartości, których nośnikiem jest nabyty produkt lub usługa, z wartościami, których się spodziewał przed dokonaniem transakcji zakupu i konsumowania nabytego produktu lub usługi. Wartościowanie będące częścią tego psychologicznego procesu obejmuje nie tylko porównanie reklamowanych wartości przed transakcją z wartościami postrzeganymi po dokonaniu, ale także szacowanie stopnia prawdziwości informacji marketingowych i handlowych.

Poczucie sprawiedliwości w transakcji typu B2C jest zależne od wielu czynników ekonomicznych i pozaekonomicznych oraz od tzw. wiedzy i orientacji rynkowej konsumenta i jego doświadczenia życiowego. Dlatego w badaniach racjonalności, efektywności konsumpcji i zachowań konsumentów, które należą do najważniejszych we współczesnej ekonomii, marketingu i naukach o zarządzaniu, satysfakcja konsumenta jest jedną z kluczowych kategorii wykorzystywanych w tych badaniach. Można zatem postawić pytania: czy zasady sprawiedliwej i uczciwej wymiany są ważną sprawą dla współczesnego marketingu? Czy połączenie sprawiedliwej i uczciwej wymiany z marketingiem i satysfakcją konsumenta ma uzasadnienie w zarządzaniu marketingiem? Czy sprawy z zakresu prawa konsumentów, będące częścią praw człowieka, powinny być zatem uwzględnione $\mathrm{w}$ zarządzaniu biznesem, $\mathrm{w}$ tym szczególnie w zarządzaniu marketingiem?

W marketingu satysfakcja jest fundamentalną zmienną. W literaturze przyznaje się jej główną rolę w budowaniu lojalności klientów. Satysfakcja w tym kontekście jest traktowana jako kluczowa zmienna, która pomaga w wyjaśnianiu poziomu lojalności, doprowadzi do powtórzenia zakupu lub kooperacji pomiędzy firmami. Lojalność klienta (customer loyalty) jest z kolei fundamentalnym celem marketingu relacyjnego [Fiol i in. 2009, s. 280-283]. 
Satysfakcja i lojalność w marketingu są silnie powiązane z wartością dla klienta. Według T. Woodalla wartość dla klienta jest głównym czynnikiem (key driver) satysfakcji i lojalności [Woodall 2003, s. 15-18]. Wartość dla klienta wzmacnia satysfakcję, a ta z kolei wzmacnia wartość i lojalność klienta. Przedsiębiorca mający lojalnych nabywców korzysta poza tym dodatkowo z marketingu szeptanego, który jest tańszy i bardzo efektywny. Wskaźnik satysfakcji skupia uwagę menadżerów na dostarczaniu konsumentom istotnych wartości. Kiedy wskaźnik satysfakcji spada, jest to ostrzeżenie, że spadek może dotknąć także sprzedaży i zysku.

Termin satysfakcja klienta (customer satisfaction) w zarządzaniu biznesem najczęściej odnoszony jest do jakości produktu i świadczonych usług. Satysfakcja ma dwa podłoża: ekonomiczne oraz psychologiczne. W wymiarze ekonomicznym satysfakcja oznacza pozytywną reakcję jednostki na otrzymaną nagrodę, dostarczaną jej przez relację, w której jednostka ta jest zanurzona. Natomiast satysfakcja psychologiczna (społeczna) jest pozytywną reakcją jednostki wynikającą z psychologicznych aspektów utrzymywanych relacji z innym członkiem (jednostką, przedsiębiorcą). Kara udzielona firmie przez konsumenta w przypadku braku satysfakcji bywa dotkliwa, gdy jest nią odejście do konkurenta, porzucenie firmy lub odrzucenie jego oferty. Z kolei satysfakcja odczuwana przez konsumentów jest głównym czynnikiem zatrzymania klienta. Zadowoleni klienci są bardziej lojalni, kupują częściej i więcej, są też mniej wrażliwi na zmiany cen, bardziej obojętni na oferty konkurencyjne. Szacuje się, że koszt utrzymania lojalnego klienta jest pięciokrotnie niższy niż koszt pozyskania nowego klienta [Siemieniako, Urban 2003, s. 12-18].

Realizacja zasady sprawiedliwej i uczciwej wymiany poprzez model satysfakcji konsumenta ma zdecydowanie szerszy wymiar aniżeli sprowadzenie jej do koncepcji sprawiedliwej ceny. W dobie wyedukowanego konsumenta, bogactwa substytutów oraz wysokiego poziomu konsumpcji życia o satysfakcji decyduje więc nie tylko relacja ceny do jakości oraz parametry użytkowe produktu, ale także oportunistyczne lub niezgodne z prawem podejście do konsumenta po zawarciu umowy sprzedaży, przy składaniu i rozpatrywaniu jego uwag, skarg lub reklamacji.

Generalnie można wskazać, iż wymiana będzie sprawiedliwa i uczciwa, gdy odczuwana satysfakcja konsumenta w wymiarze psychologicznym będzie miała charakter pozytywny albo przynajmniej neutralny. Wymiana będzie niesprawiedliwa, gdy odczuciem konsumenta będzie niezadowolenie, poczucie niesprawiedliwości i pokrzywdzenia, które może być pochodną zbyt wysokiej ceny w stosunku do rzeczywistej jakości towaru, niższych lub braku wartości, których nośnikiem miały być zakupiony towar lub usługa.

\section{Modele satysfakcji klienta a sprawiedliwość wymiany}

Satysfakcję klienta mierzy się poprzez przeprowadzanie sondażu diagnostycznego. Metoda ta pozwala na poznanie określonego zjawiska społecznego i jego cech charakterystycznych takich jak: zasięg, poziom oraz intensywność. Najczęściej stosowanymi technikami badawczymi w sondażu są ankieta, wywiad i obserwacja. 
Satysfakcja konsumenta nie jest definiowania jednoznacznie. W literaturze występuje kilka modeli satysfakcji, które różnią się kategoriami i kryteriami ocennymi badania i wyrażania satysfakcji przez badanych klientów. Pierwszym modelem jest model emocjonalny, zwany także modelem satysfakcji atrybucyjnej, traktujący satysfakcję jako stan odczuwania pozytywnych lub negatywnych reakcji emocjonalnych z faktu zakupu lub/i użytkowania produktu w kategoriach:

- sukces - porażka,

- sprawiedliwość - oszustwo,

- zadowolenie - niezadowolenie,

- radość - smutek,

- przyjemność - złość.

Drugim modelem jest model sprawiedliwej wymiany. Bazuje on na teorii wymiany sprawiedliwej opartej na zasadzie ekwiwalentności wymiany. W modelu tym satysfakcja występuje wówczas, gdy współczynnik zysków i kosztów konsumenta oraz sprzedającego są w przybliżeniu równe. Jeżeli współczynnik ten jest mniej korzystny u konsumenta, doznaje on uczucia „niesprawiedliwości wymiany” z powodu zakłócenia norm społecznych związanych ze sprawiedliwością.

Modelem, w którym dla wyrażenia satysfakcji połączone zostały użyteczność i stany emocjonalne, jest model niezgodności. Oparty jest on na oczekiwaniach, które wyznaczają standardy ewaluacji. Warunkiem satysfakcji jest oczekiwana pozytywna niezgodność pomiędzy standardami a rezultatami zachowania konsumenckiego. Im większa jest ta niezgodność, tym wyższe są warunki do powstawania emocjonalnej bazy satysfakcji. Model ten zawiera trzy poziomy satysfakcji:

1) poniżej oczekiwań (niezgodność negatywna),

2) zgodny z oczekiwaniami,

3) powyżej oczekiwań (niezgodność pozytywna).

W przypadku potwierdzenia własnych oczekiwań konsument nie doświadcza pozytywnych emocji. Oczekiwał on takiego rezultatu, nie ma więc powodu do odczuwania satysfakcji. Jeżeli rezultaty użycia lub jakość przewyższają oczekiwania konsumenta, wówczas doświadcza on oczekiwanej pozytywnej niezgodności. Stan ten wpływa na poczucie silnej satysfakcji. Z kolei gdy są one poniżej oczekiwań, doznaje dyskomfortu.

Modelem, w którym sprawiedliwość wymiany jest bardziej widoczna, jest model Kano zawierający trzy rodzaje satysfakcji:

1) konieczną - gdy dochodzi do zaspokojenia potrzeb podstawowych,

2) jednowymiarową - gdy następuje zaspokojenie potrzeb negocjowanych,

3) satysfakcję ponad oczekiwania - gdy dochodzi do zaspokojenia potrzeb dodatkowych.

Satysfakcja odczuwana przez konsumenta, czyli doznawanie pozytywnych emocji, następuje wówczas, gdy we wszystkich tych obszarach oczekiwania konsumenta zostały przewyższone lub co najmniej się spełniły. W przypadku przewyższenia spodziewanych wartości wchodzimy na wyższy stopień satysfakcji, czyli dochodzi do 
progresji satysfakcji, którego trafnym określeniem może być zachwyt. Jeśli oczekiwania są poniżej progu spodziewanych wartości, to następuje dyssatysfakcja wyrażana stanem niezadowolenia, irytacją i podobnymi odczuciami skłaniającymi konsumenta do zachowań roszczeniowych. Kosztem takiego niezadowolenia dla sprzedawcy może się stać utrata klienta, pogorszenie wizerunku i reputacji rynkowej, a także koszty finansowe w wyniku przegrania sporu sądowego.

W modelu Kano satysfakcja jest rozdzielona na trzy wieloaspektowe wymiary. Łączy ona wartości zawarte w: parametrach fizycznych produktu, poziomie ceny, wymianie informacji, relacji między konsumentem i sprzedawcą, jakości obsługi, kulturze personelu, usługach serwisowych, zasadach reklamacji.

Wieloaspektowym modelem satysfakcji w kontekście sprawiedliwej wymiany jest model Prosat, ogarniający zarówno wartości dostarczane konsumentom, jak i wartości oczekiwane przez konsumenta. Zawiera on pięć następujących wymiarów:

1) techniczna jakość produktu: parametry użytkowe, niezawodność, zastosowanie, jakość, bezpieczeństwo, ekologiczność;

2) jakość opinii: subiektywny stosunek konsumenta do firmy i jego oferty;

3) postrzeganie ceny: poziom ceny, rabaty, wybór zapłaty, zmiany cen;

4) jakość osobistej relacji: jest to wynik doświadczeń z komunikacji osobistej z personelem firmy, kompetencji personelu, sposobu rozwiązywania konfliktów i skarg;

5) jakość serwisu: dyspozycyjność personelu, wygoda i reprezentacyjność budynków, pawilonów handlowych, stosowane techniki komunikacyjne i relacyjne $\mathrm{z}$ klientem.

W psychologii konsumenta występuje także satysfakcja w ujęciu funkcjonalnym, na którą składają się satysfakcja transakcyjna oraz satysfakcja skumulowana. Jeżeli nabywanie towaru podzielimy na trzy fazy, tj. fazę przedtransakcyjną, transakcyjną i posttransakcyjną, to satysfakcja transakcyjna odnosi się do dwóch pierwszych faz. A zatem ten rodzaj satysfakcji związany jest z zadowoleniem towarzyszącym procesowi nabycia towaru i występuje od transakcji do transakcji. Inaczej jest z satysfakcją skumulowaną. Nie jest ona przemijającym i krótkotrwałym stanem zadowolenia. Jest to całkowita ocena konsumpcji w określonym przedziale czasu - z okresu użytkowania towaru. Może wynikać np. z takich kategorii, jak cykl życia ceny, cykl życia produktu, jakość, funkcjonalność, prestiż, w ewaluacji których kryterium sprawiedliwej wymiany będzie istotnie ważyło w odczuwanej satysfakcji skumulowanej.

Jak więc wynika z powyższego, sprawiedliwa i uczciwa wymiana, stanowiąc istotny czynnik satysfakcji konsumenta, staje się ważnym aspektem w zarządzaniu marketingiem, co uwidacznia przywoływana już triada: marketing - satysfakcja - lojalność. Sprawiedliwa wymiana i odczuwana satysfakcja konsumenta zaś, jak wskazano wcześniej, zależą w dużej mierze od przestrzegania w marketingu praw konsumentów, które są naruszane w sposób świadomy i celowymi działaniami marketingowymi przez przedsiębiorców. Powstaje więc pytanie: czy we współczesnych koncepcjach marketingu chronione prawem prawa konsumentów, które są odzwierciedleniem idei sprawiedliwej i uczciwej wymiany, powinny się stać integralną częścią marketingu 
oraz czy współczesne teorie marketingu zawierają przestrzeń dla implementacji tej nowej wartości w marketingu?

\section{Kryteria sprawiedliwej i uczciwej wymiany w marketingu}

Zgodnie ze współczesną logiką zarządzania biznesem firmy mają się skupiać nie na maksymalizowaniu zysku, lecz na maksymalizowaniu wartości oferowanych klientowi. Klienci bowiem kupują raczej wartości aniżeli produkty i usługi. Propozycja wartości wymaga zdefiniowania tego, co produkt będzie oferował klientowi oraz w jaki sposób klient będzie mógł go wykorzystać, a także zaplanowania sposobu przekazania mu tych wszystkich informacji. Kluczowy zbiór wartości dla klienta stanowią te wartości użytkowe produktu, które są zdolne do zaspokajania potrzeb klienta i rozwiązywania jego określonych problemów, a także budowania przewag nad konkurentami czy też realizacji innych ważnych celów konsumenta. Na wartości te składają się: (i) wartości ekonomiczne, tj. sprawiedliwa cena jako relacja wartości do jakości oraz kosztów użytkowania, (ii) wartości symboliczne, jak prestiż, status społeczny, odmienność, styl; (iii) wartości emocjonalne, czyli satysfakcja, zadowolenie, radość; (iv) wartości sensoryczne, tj. zapach, smak, dotyk, dźwięk, kolor; (v) wartości funkcjonalne, jak wygoda w użytkowaniu; (vi) wartości etyczne, tj. uczciwość, wiarygodność i rzetelność przedsiębiorcy; (vii) wartości prawne, czyli prawość i przestrzeganie prawa.

W związku z tymi wartościami konsumenci na rozwiniętym i konkurencyjnym w substytuty rynku w relacji z przedsiębiorcą wymagają zarówno wysokiej jakości zakupywanych towarów lub usług, jak i uczciwego oraz rzetelnego marketingu, prawdziwych i pełnych informacji handlowych oraz obsługi na najwyższym poziomie i to w każdej fazie cyklu wymiany. W fazie przedtransakcyjnej oczekują uczciwego i rzetelnego marketingu, w fazie transakcji - profesjonalnej i kompleksowej obsługi oraz ceny adekwatnej do jakości, w fazie posttransakcyjnej - potwierdzenia się w procesie użytkowania towaru jego wartości zachwalanych w fazie przedkontraktowej oraz respektowania praw konsumenta do składania skarg i reklamacji.

W modelach marketingu a przede wszystkim 4P i 7P, przedsiębiorcy koncentrują się głównie na stymulacji produkcji, sprzedaży i konsumpcji. Wprawdzie w koncepcji marketingu zrównoważonego, która pojawiła się pod koniec lat 90., mówi się o potrzebie pobudzania sprzedaży i konsumpcji z dużo bardziej zrównoważonym wykorzystaniem zasobów naturalnych i materialnych, poprzez skoncentrowanie się na trzech aspektach: ekologicznym, społecznym i ekonomicznym [Rudawska 2013, s. 81-82], to w aspekcie ekologicznym głównie chodzi o przestrzeganie przepisów ochrony środowiska, a w społecznym - o cele, które wchodzą w zakres CRS. Nie dostrzega się natomiast praw konsumentów. Dokłada się do marketingu nowe perspektywy budowania relacji z klientem w celu otaczania go coraz to nowymi i rzekomo niezbędnymi wartościami, ale bez uwzględniania obowiązku przestrzegania jego praw zapisanych $\mathrm{w}$ prawie ochrony konsumentów, $\mathrm{w}$ tym prawie do sprawiedliwej i uczciwej wymiany. 
Sprawiedliwość i uczciwość w relacjach typu B2C powinny się stać fundamentalną wartością lub zasadą, na której powinny być oparte relacje między przedsiębiorcą a konsumentem i teorie marketingu powinny się do tej perspektywy odwoływać. Zasada ta winna stać się ważną ideą marketingu zrównoważonego. Dochowywanie zasady sprawiedliwości w konsumenckim obrocie nie powinno być tylko gwarantowane i wymuszane przez odpowiednie regulacje prawne, które nakazują przedsiębiorcom w relacjach typu B2C przestrzegania wskazanych zachowań i działań oraz zakazują nagannych praktyk rynkowych, które naruszają określone przez ustawodawcę interesy konsumentów. Praktyki marketingowe zakłócające zasadę sprawiedliwej i uczciwej wymiany są częścią nieuczciwych praktyk rynkowych godzących w ekonomiczne interesy konsumenta. Ich definicja prawna, wskazując na reklamę i marketing, informacje handlowe bezpośrednio związane z promocją lub nabycie produktu przez konsumenta, odnosi się wprost do marketingu mix (4P i 7P).

Odpowiadając zatem na postawione wcześniej pytanie o miejsce dla zasady sprawiedliwej i uczciwej wymiany w marketingu, która w imię szybkiego i łatwego zysku jest lekceważona, można uznać, że takie miejsce i przestrzeń istnieje w koncepcji marketingu zrównoważonego (sustainable marketing). Przez marketing zrównoważony rozumie się ,proces zaspokajania potrzeb konsumentów i społeczeństwa poprzez planowanie i urzeczywistnianie koncepcji korzyści, kosztów, komunikacji oraz wygody związanych z oferowanym produktem, w sposób satysfakcjonujący strony wymiany i równocześnie zgodny z zasadami zrównoważonego rozwoju" [Zaremba-Warnke 2015, s. 102]. Koncepcja ta integruje cele społeczne, ekonomiczne, ekologiczne, w kontekście utrzymywania poprawnych relacji z otoczeniem. Położenie nacisku na cele społeczne jest zgodne z rosnącą wrażliwością konsumentów na działalność biznesu i wzrostu poziomu edukacji konsumentów, o czym świadczy rosnąca liczba skarg i pozwów zbiorowych wytoczonych biznesowi w związku z nieuczciwymi praktykami naruszającymi zasadę sprawiedliwej wymiany. Istotnym elementem sprawiedliwej wymiany i równego traktowania jest również zorganizowanie przez biznes łatwego i taniego dostępu do rozwiązywania sporów konsumenckich, niezależnie od tego, czy przyczyna tego sporu leży po stronie przedsiębiorcy, czy konsumenta. Nieuwzględnianie zatem w marketingu zrównoważonym gwarantowania podstawowych praw konsumenta jest jego ułomnością, skoro odwołuje się do respektowania celów społecznych. Koncepcja marketingu zrównoważonego zatem powinna zostać poszerzona o postrzeganie idei sprawiedliwej i uczciwej wymiany silnie umocowanej w prawach konsumenta. Natomiast poszerzenia marketingu o ideę sprawiedliwej i uczciwej wymiany wynikającej z prawa ochrony konsumenta nie należy łączyć z marketingiem społecznym. Marketing społeczny bowiem polega na uświadamianiu publiczności potrzeby zmiany stylu życia, przeciwdziałania patologiom społecznym, nagłaśnianiu problemów społecznych, wspieraniu skuteczności realizacji programów społecznych i innych celów non-profit [Iwankiewicz-Rak 2014 s. 463]. 


\section{Marketing $4 \mathrm{C} w$ jako integrator zasady sprawiedliwej wymiany i uczciwego traktowania konsumenta}

Potencjał do uwzględniania zasady sprawiedliwości i uczciwej wymiany w marketingu stwarza szczególnie operacyjny model marketingu 4C. Koncepcję marketingu 4C w 1990 r., jako alternatywę dla 4P, przedstawił R. Lauterborn. Jego filozofia marketingu zmieniła orientację z opcji menedżerskiej na opcję klienta. Według niego formuła 4P odzwierciedla punkt widzenia menedżera ds. marketingu (perspektywa wewnętrzna), choć w marketingu wymaga się od wszystkich przyjęcia perspektywy klienta (perspektywa zewnętrzna) [Burgers 2010, s. 34-44].

Pierwszym jego elementem są potrzeby i pragnienia (customer value), czyli wartości i korzyści, które osiągnie konsument wraz z zakupem oferowanego produktu lub usługi. Do wartości tych zalicza się ekonomiczną, użytkową, emocjonalną, sensoryczną, symboliczną. Są one związane z zestawem określonych cech produktu, takich jak jakość, cena, funkcje, wygoda, bezpieczeństwo, ekologiczność, estetyka, prestiż itp.

Drugim elementem są koszty dla klienta (cost to the consumer). W tym elemencie koszty powinny być dostosowane do możliwości finansowych klienta. Chodzi tu nie tylko o cenę zakupu, ale także o koszty użytkowania (cykl życia ceny). W koszty wchodzi nie tylko wydatek pieniężny, ale także wysiłek wniesiony w zakup oraz koszty poniesione w związku z ewentualnym dochodzeniem swoich praw w procesie reklamacji.

Trzecim jest wygoda zakupu (convenience), a więc cała obsługa klienta, organizacja sprzedaży, formy zapłaty, dostawa towaru. Niewątpliwe w tym elemencie mieści się również dogodność zwrotu towaru, składania skarg i reklamacji oraz sposoby rozpatrywania i rozstrzygania sporów z konsumentami.

Czwartym elementem jest komunikacja (communication). Zwykle wymienia się tutaj takie aspekty komunikacji, jak przejrzysty oraz niewprowadzający w błąd przekaz reklamowy, rzetelny, pełny i czytelny przekaz informacji handlowej i innych danych na temat dostępnej oferty. Zapomina się jednak o takim przekazie informacji, który dotyczy praw konsumenta, np. prawa do reklamacji, prawa do zwrotu towaru, gdy zakup nastąpił na odległość lub poza siedzibą przedsiębiorstwa, o ryzykach związanych z zakupem, np. w zakresie kosztów użytkowania, ryzyku finansowym.

Struktura modelu 4C wskazuje, że jego cechą wyróżniającą jest holistyczne podejście do klienta. To holistyczne podejście polega na położeniu akcentu nie tylko na wybranych czynnikach, które zwiększają sprzedaż, ale również na czynnikach, które mają wpływ na generowanie szerokiego spectrum wartości. Sprawia to, że konsument wynosi więcej zadowolenia i satysfakcji w każdej fazie relacji z przedsiębiorcą. Tym samym stanowi on dobry grunt dla uwzględniania zasady sprawiedliwej wymiany i uczciwego traktowania konsumenta jako jednej z tych wartości. Model 4C może zatem stać się efektywną platformą do zintegrowania praw konsumenta z marketingiem. 


\section{Zakończenie}

Różne aspekty marketingu stosowanego, naruszającego zasadę sprawiedliwej wymiany zostały przedstawione $\mathrm{w}$ niniejszym opracowaniu nie $\mathrm{z}$ punktu widzenia etyki działań marketingowych i odwoływania się do normatywnego modelu etycznego w marketingu lub marketingu „dobrego” oraz „złego”. Nie bagatelizując etyki w marketingu, autor opracowania twierdzi, że istotną luką jest nieobejmowanie i niewprowadzanie do kolejnych koncepcji i idei marketingu wartości wynikających z praw konsumentów. Jest to zastanawiające tym bardziej, kiedy mówi się o społecznych aspektach marketingu, o tym, że marketing nie powinien być ograniczony tylko do funkcji sprzedaży, w następstwie czego zintegrowano z nim w marketingu ekologicznym i zrównoważonym zagadnienia z zakresu ekologii i społecznej odpowiedzialności biznesu. Z rozważań wynika jednak, że wciąż kluczowa wartość dla konsumenta, którą stanowi zasada sprawiedliwej i uczciwej wymiany, jest w marketingu pomijana. Bez włączenia do marketingu wartości wynikających z praw konsumenta koncepcja marketingu zrównoważonego i społecznie odpowiedzialnego wydaje się niekompletna. Realizacja marketingu opartego na wartościach, co akcentuje model marketingu 3.0, a którego naturalną kontynuacją jest marketing 4.0 [Kotler, Kartajaya, Setiawan 2017, s. 14], wymaga więc inkluzji również tych wartości, które są promowane przez politykę konsumencką. W związku ze zmianą układu sił na rynku, wynikającą, jak twierdzi Kotler, z przechodzenia władzy w ręce klientów, firmy, które są nieuczciwe i oferują słabe produkty, nie przetrwają na rynku [Kotler, Kartajaya, Setiawan 2017, s. 19-29]. Wartość w postaci sprawiedliwej i uczciwej wymiany może więc się stać symbolem marketingu „o ludzkiej twarzy”.

\section{Literatura}

Burgers W., 2010, Marketing bez tajemnic, Wolters Kluwer, Warszawa.

Fiol L.J.C, Alcañiz E.B., Moliner Tena M.A., Sánchez García J., 2009, Customer loyalty in cluster: Perceived value and satisfaction as antecedents, Journal of Business-to Business Marketing, vol.16, issue 3.

Iwankiewicz-Rak B., 2014, Marketing społeczny w praktyce organizacji niebiznesowych, Marketing i Rynek, $\mathrm{nr} 8$.

Jurczyk Z., 2016, Polityka ochrony konsumentów w Polsce, [w:] Styś A., Łobos K. (red.), Wspótczesne problemy zarzadzania i marketingu, Difin, Warszawa.

Kodeks cywilny, 2016, Warszawa.

Kotler Ph., Kartajaya H., Setiawan I., 2017, Marketing 4.0, MT Biznes, Warszawa.

Macko M., 2009, Poczucie sprawiedliwości organizacyjnej a zachowania pracowników, Wydawnictwo UAM w Poznaniu, Poznań.

Przybyłowski K., Hartley S.W., Kerin R.A, Rudelius W., 1998, Marketing, Warszawa.

Rudawska E., 2013, Marketing zrównoważony - nowe oblicze kapitalizmu, Ekonomia Economics 3(24), Uniwersytet Szczeciński.

Siemieniako D., Urban W., 2003, Modele lojalności klientów - rola satysfakcji oraz kierunki badań, Marketing i Rynek, nr 8. 
Ustawa z dnia 23 sierpnia o przeciwdziałaniu nieuczciwym praktykom rynkowym (DzU 2007, nr 171, poz. 1206; tj. DzU 2017, poz. 2070).

Ustawa o zwalczaniu nieuczciwej konkurencji, Komentarz, 2016, red. M. Zdyb, M. Sieradzka i in., Warszawa.

Woodall T., 2003, Conceptualising value for the customer: A structural, attributional and dispositional perspective, Academy of Marketing Science Review, no. 12, www.amsreview.org/articles/woodal (04.2018).

Zaremba-Warnke S., 2015, Marketing zrównoważony jako narzędzie doskonalenia przedsiębiorstwa, Prace Naukowe Uniwersytetu Ekonomicznego we Wrocławiu, nr 376. 